\title{
Influence of Brand Personality on Purchase Decisions: A Case Study of Nike Shoes in Ambon City
}

\author{
Merry M. Pelupessy ${ }^{1)}$, Erlinda Tehuayo ${ }^{2)}$ \\ Faculty of Economic and Business, Universitas Pattimura, Indonesia \\ Email: merrypelupessy77@gmail.com ${ }^{1)}$
}

\begin{abstract}
The purpose of the study was to analyze the influence of brand personality on purchasing decision for Nile shoes in the city of Ambon. this research is a descriptive research. The population in this study are users of nike shoes in Ambon city. And The Number Of Sampel Is 100 respondents.By using a questionnaire as a data collection tool. Taking the sample using non probability sampling with the data analysis method used is multiple linear regression. Based on the results of multiple linear regression test that the brand personality variable has a positive and significant effect on the decision of 0,396 which means that the brand personality variable is considered important when consumers will make a decision to buy nike shoes.
\end{abstract}

Keywords : brand personality, purchase decision

\section{Introduction}

Fashion developments are constantly evolving, as are the current shoe trends. Following the latest trends is a must. Various shoes with unique and beautiful trends have sprung up, such as formal style shoes that had become a trend in 2013 which are usually widely used by men and women to go to formal and semi-formal events.

Shoes are a type of footwear which usually consists of the soles, heels, hood, laces and tongue (Pabichara: 2013). Usually also made of canvas or leather that covers all parts from the toes, instep to the heel. The grouping of shoes is usually done based on the function or type such as: formal shoes (party), casual shoes (casual), dance shoes, sports shoes, work shoes, orthopedic shoes and minimalist shoes. Shoes have now become a basic need from children to adults.

Shoes industry products are also very competitive in terms of shape, color, technological sophistication, and brand. Shoe brands circulating in the sports industry market in Indonesia today come from various countries including America, Europe and Asia such as Nike, Adidas, Puma, Diadora Umbro, Lotto, Kappa, Kelme, and Joma. These brands are in great demand by the people of Indonesia. There are also domestic products that are very popular, including League, Specs, and Miter. Each brand offers its own services for its customers, to the setting of prices that are quite competitive according to the type and market segment.

Brand personality is the set of human characteristics associated with a brand. Emari Hossien also defined personality in terms of characteristics instead of traits and carefully developed 44 items on the brand personality scale covering five dimensions: sincerity, passion, competence, sophistication and toughness.

Effective consumer decisions, lead to an intention to buy a product which ultimately leads to the company's expectations. According to Bouhlel et al., (2009), purchase intention is the probability of purchasing a product with what the brand can provide. 
Consumers today are also very critical in choosing a product, until the decision to buy the product. As we all know that the current product offerings are very diverse and numerous, including shoe product advertisements, which are experiencing very rapid development. More and more alternative choices make it easier for consumers to make choices according to their tastes and economic capabilities. Therefore, by maintaining quality and model, producers can attract and make consumers buy and loyal to the product.

For example, Nike shoes that have one of the advantages are that they have All Conditions Control (ACC) technology, this technology is made to welcome the spring and rainy season like Nike soccer shoes that already have technology (ACC) to maintain the level of friction, touch and ball control. The same applies to both wet and dry conditions, apart from ACC technology, Nike is also innovating with another technology called Green Speed. This technology is an environmentally friendly technology that is not owned by other Nike competitors so that this advantage is one of the considerations for consumers to make purchasing decisions.

Table 1. Results of phase 2 top brand index for sports equipment category sports shoes products

\begin{tabular}{|c|c|c|c|}
\hline Brand & $\begin{array}{c}\text { Top Brand Index } \\
2018\end{array}$ & $\begin{array}{c}\text { Top Brand Index } \\
2019\end{array}$ & $\begin{array}{c}\text { Top Brand Index } \\
2020\end{array}$ \\
\hline Adidas & $37.4 \%$ (Top) & $38.2 \%$ (Top) & $37.6 \%$ (Top) \\
\hline Nike & $29.6 \%$ (Top) & $32.2 \%$ (Top) & $25.6 \%$ (Top) \\
\hline Reebok & $3.7 \%$ & $3.3 \%$ & $6.2 \%$ \\
\hline Bata & $3.6 \%$ & - & - \\
\hline Eagle & $3.0 \%$ & $3.3 \%$ & - \\
\hline
\end{tabular}

Source: www.topbrand-award.com

The table 1 shows that the Nike brand is at a fairly high percentage in 2018 and 2020. The percentage increase is $2.6 \%$, this shows that there has been an increase in purchasing decisions in the last 2 years for Nike shoes in Indonesia.

In addition, if we look at 2020 the percentage of the Nike brand has decreased by $6.6 \%$ for 2018 to 2019 . This is probably the result of increasingly fierce competition and changing consumer trends.

The formulation of the problem in this study is whether brand personality has an effect on purchasing decisions for Nike shoes in the city of Ambon. Research Objectives To examine and analyze the effect of Brand Personality on Purchase Decisions for Nike shoes in Ambon city.

\section{Literature Review}

\subsection{Brand Personality}

Brand personality is an interesting and important topic in today's marketing research because it can help to distinguish a brand from other brands, build emotional aspects, and enlarge the personal meaning of a brand.

Brand personality is formed through consumer attitudes towards certain brands (Kapferer: 
2008). In other words, the personality of a brand is in the minds of consumers or perceptions that are formed directly or indirectly through direct experience using the product or through marketing efforts.

Kotler and Keller (2012: 179) define brand personality as "the specific mix of human traits that we can attribute to a particular brand".

The three indicators used to measure Brand Personality according to (Aaker, Suparna, et al, 2018) are (Sincerity) this dimension shows sincere human nature which is reflected in the nature of multiplicity, loving family, honest, challenging, helpful, cheerful, sentimental and easy. get along. Sincerity reflects how the brand is really able to show consistency in meeting the needs, desires, and expectations of consumers. (Joy) can give joy or comfort to the wearer. It draws on the nature of being independent, youthful, calm, passionate and courageous. (Sophistication) dimensions that can appear to have characteristics such as upper class, glamorous, attractive, charming, feminine and gentle. The sophistication dimension for consideration for a brand provides value to the wearer.

\subsection{Buying decision}

The decision made by consumers on a product or service is a process of evaluating and receiving brand information, considering how other brands can meet consumer needs and ultimately deciding which brand to choose (Wijayanti: 2008). The desire to buy on consumers will arise when they feel interested, want to use, and have the product they see.

\subsection{Previous Research}

Research conducted by Rossa Ocktaria, Srikandi Kumadji and Kadarisman Hidayat (2015) with the research title "The influence of brand personality and sales promotion on brand equity and purchasing decisions (a survey of students using Wardah cosmetics products at Brawijaya University Malang.

Research conducted by Alwis, Rika Desiyanti and Mery Trianita (2013) with the title "the influence of brand personality and brand equity on purchasing decisions of Canon SLR Cameras in Padang City". From the results of this study, the brand personality variable has a positive effect on purchasing decisions. The results of this study indicate that brand personality has a positive effect on purchasing decisions

\subsection{Hypothesis Development}

The Influence of Brand Personality on Purchase Decisions

Brand personality is an interesting and important topic in today's marketing research because it can help to distinguish a brand from other brands, build emotional aspects, and enlarge the personal meaning of a brand.

Brand personality is formed through consumer attitudes towards certain brands (Kapferer: 2008). In other words, the personality of a brand is in the minds of consumers or perceptions that are formed directly or indirectly through direct experience using the product or through marketing efforts. Kotler and Keller (2012: 179) define brand personality as "the specific mix of human traits that we can attribute to a particular brand".

From the results of research conducted by Rossa Ocktaria, Srikandi Kumadji and Kadarisman Hidayat (2015) it shows that brand personality has a positive effect on purchasing decisions with a path coefficient value of $0.316(\mathrm{p}<0.05)$. 
From the results of research conducted by Alwis, Rika Desiyanti and Mery Trianita (2013), it shows that the brand personality variable has a positive effect on purchasing decisions for Canon SLR cameras in the city of Padang.

H1: Brand Personality Positively Affects Purchase Decisions

\section{Research Method}

Data analysis method used in this research is quantitative analysis method. To analyze the influence of Brand Personality on Purchase Decisions is to use multiple linear regression analysis (Multiple Regressional Analysis). The analysis used to determine how much influence more than one independent variable has on one dependent variable Ghozali (2006).

\subsection{Population and sample}

The population in this study are consumers who use Nike shoe products in the city of Ambon. The sample is part or elements of the population, Indriantoro and Supomo (2002). The method used in sampling is Non Probability Sampling, which is a sampling method that does not provide equal opportunities or opportunities for each element or member of the population to be selected as a sample because certain considerations are considered. The sample in this study were users of Nike shoe products in the city of Ambon. In determining the sample if the population is large and the number is unknown, according to Rao Purba, use the following formula.

$\mathrm{n}=\frac{\mathrm{Z}^{2}}{4(\mathrm{Moe})^{2}}$

By using the above formula, the number of samples taken is 96 respondents.

\subsection{Data Collection Technique}

In conducting research, the data collected will be used to solve existing problems so that the data must be truly reliable and accurate. The data used in this study were obtained through the questionnaire method, namely data collection techniques carried out by giving questionnaires or a set of questions or written statements to respondents, Sugiyono (2001).

\subsection{Variable Operational Definition and Variable Measurement}

Brand Personality is defined as a brand personality that represents and describes the human personality. (Aaker, Suparna, et al, 2018). With indicators of Sincerity, Joy and Sophistication. Purchase decision is the action of consumers to buy or not to the product. Kotler (1995: 70). With indicators of stability in a product, habits in buying products and providing recommendations to others.

\subsection{Analysis Technique}

This study uses multiple linear regression analysis model to prove the research hypothesis. The analytical technique used in this research is to use the SPSS (Statistical Package For Social Science) program for windows.

\section{Findings and Discussions}

Descriptive analysis can be used to determine the minimum and maximum size, standard deviation and variance of a data. The results of the descriptive analysis obtained from Brand Personality (X1) and Purchase Decision (Y) are presented in Table 2.

Table 2. Brand Personality Descriptive Statistics (X1) and Purchase Decision (Y)

\begin{tabular}{|c|c|c|}
\hline Descriptive & Buying decision & Brand Personality \\
\hline
\end{tabular}




\begin{tabular}{|l|r|r|}
\hline & (Y) & \multicolumn{2}{|c|}{ (X) } \\
\hline $\mathrm{N}$ & 100 & 100 \\
\hline Minimum & 8 & 8 \\
\hline Maximum & 15 & 15 \\
\hline Mean & 12,93 & 13,54 \\
\hline Std. Deviation & 1,66 & 1,36 \\
\hline
\end{tabular}

Based on table 2, it can be seen that the Purchase Decision obtained a minimum value of 8 , a maximum value of 15, an average value (mean) of 12.93 and a standard deviation value (Std. Deviation) of 1.66. Meanwhile, Marek's Personality got a minimum score of 8 , a maximum value of 15 , an average value (mean) of 13.54 and a standard deviation of 1.36 .

The results of data processing using SPSS in this study are shown in table 3 as follows Table 3. Partial Significance Test Results (t Test)

\section{Coefficients $^{\mathrm{a}}$}

\begin{tabular}{|c|c|c|c|c|c|c|c|c|}
\hline \multirow{2}{*}{\multicolumn{2}{|c|}{ Model }} & \multicolumn{2}{|c|}{$\begin{array}{l}\text { Unstandardized } \\
\text { Coefficients }\end{array}$} & \multirow{2}{*}{$\begin{array}{c}\begin{array}{c}\text { Standardized } \\
\text { Coefficients }\end{array} \\
\text { Beta }\end{array}$} & \multirow[b]{2}{*}{$\mathrm{t}$} & \multirow[b]{2}{*}{ Sig. } & \multicolumn{2}{|c|}{$\begin{array}{l}\text { Collinearity } \\
\text { Statistics }\end{array}$} \\
\hline & & B & Std. Error & & & & $\begin{array}{c}\text { Toleranc } \\
\mathrm{e}\end{array}$ & VIF \\
\hline \multirow[t]{2}{*}{1} & (Constant) & 1,761 & 1,513 & & 1,164 & 247 & & \\
\hline & $\begin{array}{l}\text { Brand } \\
\text { Personality }\end{array}$ & ,482 &, 116 & ,396 & 4,166 & ,000 &, 723 & 1,382 \\
\hline
\end{tabular}

Dependent Variable : Purchase Decision

Source: Results of data processing with SPSS.25 ( 2021 )

From the multiple linear regression test, it shows that for the brand personality variable (X1), the t-count value is $4.166(4.166>1.975)$. Thus the H1 hypothesis in this study is accepted, namely that there is a positive and significant influence of brand personality on purchasing decisions for Nike shoes in Ambon city. These results indicate that the brand personality which includes Sincerity, Joy and Sophistication is one of the considerations for consumers in making purchasing decisions for Nike shoe products. Kotler and Keller (2012: 179) define brand personality as "the specific mix of human traits that we can attribute to a particular brand".

The results of this study are in line with previous research conducted by Rossa Ocktaria, Srikandi Kumadji and Kadarisman Hidayat (2015) with the title "The influence of brand personality, sales promotion on brand equity and purchasing decisions (a survey of students using wardah cosmetic products at Brawijaya University Malang)" The results of the study stated that the brand personality variable had a positive effect on purchasing decisions. 


\section{References}

Djaali. (2008). skala likert. Jakarta: Pustaka Utama.

Ghozali. (2001). Aplikasi Analisis Multivariate Dengan Program SPSS. Semarang: Badan Penerbit Universitas Diponegoro.

Ghozali. (2011). Aplikasi Analisis Multivariate Dengan Program SPSS. Semarang: Badan Penerbit Universitas Diponegoro.

Ghozali. (2005). Aplikasi Analisis Multivariate Dengan Program SPSS. Semarang: Badan Penerbit Universitas Diponegoro.

Sugiyono. (2001). Metode Penelitian Bisnis. Bandung: Alfabeta..

Sugiono 2012 Metode penelitian Kuantitatif R \& D Bandung Alfabeta

Sugiono Metode Penelitian Bisnis, Cetakan pertama, Penerbit CV. Alpha beta, Bandung 2004

Kotler dan Keller, 2012 Manajemen Pemasaran, Jakarta : Erlangga

Hasil Top Brand Indeks. (n.d.). Retrieved from www.topbrand-award.com

Ike Venessa \& Zainul Arifin. (2015). Pengaruh citra merek (brand image) dan harga terhadap keputusan pembelian konsumen (Survei pada mahasiswa program studi administrasi bisnis fakultas ilmu administrasi Universitas Brawijaya Malang tahun angkatan 2013 / 2014 dan 2014 / 2015 pengguna kartu P). Administrasibisnis.Studentjournal.Ub.Ac.Id, 51(1), 44-48. Retrieved from studentjournal.ub.ac.id

Kotler, P. \& K. (2009). Manajemen Pemasaran. Terjemahan Bob Sabran. Edisi ke 13. Jilid 1. Jakarta: Erlangga.

Kotler, P. \& K. K. (2008). Manajemen Pemasaran, Edisi kedua Belas jilid 1. PT. Macanan Jaya Cemerlang.

Kurnia Akbar. (2013). Analisis pengaruh harga, brand image, dan atribut produk terhadap keputusan pembelian handpone atau smartpone samsung jenis android. Retrieved from https://www.neliti.com

Matondang, Z., \& Pendahuluan, A. (2009). Validitas dan Reliabilitas suatu instrumen penelitian, 6(1), 87-97. Retrieved from https://jurnal.unimed.ac.id 